\title{
Аналіз підходів до кваліфікації на «жорсткі» умови елементів енергоблоків AEC, працездатність яких необхідна для управління важкими аваріями на AEC
}

- Сахно Олександр Володимирович, канд. техн. наук

Державне підприємство «Державний науково-технічний центр з ядерної та радіаційної безпеки», м. Київ, Україна

ORCID: https://orcid.org/0000-0003-0131-3570

- Рижов Дмитро Іванович

Державне підприємство «Державний науково-технічний центр з ядерної та радіаційної безпеки», м. Київ, Україна

ORCID: https://orcid.org/0000-0002-0068-5009

- Шугайло Олександр Петрович

Державне підприємство «Державний науково-технічний центр з ядерної та радіаційної безпеки», м. Київ, Україна

ORCID: https://orcid.org/0000-0003-1044-0299

- Хамровська Леся Володимирівна

Державне підприємство «Державний науково-технічний центр з ядерної та радіаційної безпеки», м. Київ, Україна

ORCID: https://orcid.org/0000-0003-0443-2348

\section{- Павлів Євген Андрійович}

Державне підприємство «Державний науково-технічний центр з ядерної та радіаційної безпеки», м. Київ, Україна ORCID: https://orcid.org/0000-0003-3299-8824

У статті проводиться аналіз прийнятих в Україні підходів та міжнародного досвіду 3 кваліфікації елементів діючих енергоблоків АЕС для роботи в «жорстких» умовах, що виникають за порушення умов безпечної експлуатації на АEC, включно з важкими аваріями. Визначаються ключові особливості методологічних підходів та процедур виконання робіт з кваліфікації елементів на «жорсткі» умови важких аварій, які мають бути враховані під час практичної реалізації цих заходів.

На основі результатів аналізу міжнародного досвіду і практики регулювання Комісії ядерного регулювання Сполучених Штатів Америки, а також проведеного аналізу регулюючих вимог нормативної бази України стосовно кваліфікації обладнання АЕС на «жорсткі» умови, сформовані пропозиції 3 актуалізації чинної нормативної бази України, які вказують, зокрема, на необхідність систематизації наявних та впровадження нових нормативних вимог щодо кваліфікації обладнання АЕС в межах окремого нормативного документа.

Ключові слова: атомна електростанція, важка аварія, «жорсткі» умови експлуатації, кваліфікація обладнання, нормативні вимоги.

( С Сахно О. В., Рижов Д. І., Шугайло О-р П., Хамровська Л. В., Павлів Є. А., 2021 


\section{Вступ}

Згідно $з$ рекомендаціями Міжнародного агентства 3 атомної енергії (МАГАТЕ), наведеними, зокрема, в документах [1] та [2], процес кваліфікації обладнання (КО) є складовою загальної системи забезпечення безпеки АЕC. Кваліфікація елементів та обладнання систем, важливих для безпеки (СВБ), енергоблоків АЕС, $\epsilon$ регулюючою вимогою для підтвердження спроможності відповідних систем та їх елементів виконувати функції безпеки в «жорстких» умовах (ЖУ) експлуатації з урахуванням погіршення стану обладнання внаслідок старіння.

Необхідність виконання КО енергоблоків АEC України встановлена в затвердженій Кабінетом Міністрів України Комплексній (зведеній) програмі підвищення рівня безпеки енергоблоків атомних електростанцій (К(з)ППБ) [3].

Організаційно-технічні заходи К К(з)ППБ [3] охоплюють:

виконання робіт із встановлення КО на умови проєктних аварій (ПА) - захід № 10101 (20101, 30101);

оцінку стану КО на ЖУ, які можуть мати місце під час та після важких аварій (ВА) - захід № 10102 (20102, 30102).

Одним 3 критеріїв ефективності діяльності експлуатуючої організації (EO) з КО АEC згідно 3 [1], [2] $\epsilon$ наявність відповідних програмних і методичних документів та відповідність їх положень актуальним регулюючим вимогам.

\section{Регулюючі вимоги щодо КО АЕС України, важливого для безпеки, на умови ПА}

Наразі основні регулюючі положення та вимогищодоКОАЕСмістятьсявнизцінормативноправових актів України з ядерної та радіаційної безпеки (ЯРБ) [4]-[8]. Власне, визначення терміну «кваліфікація обладнання» наведене в НП 306.2.141-2008 [4], згідно з яким КО - це «підтвердження того, що конструкція, система (елемент) у межах усього терміну експлуатації будуть виконувати покладені функції як при нормальній експлуатації, так і проєктних аваріях 3 урахуванням характеристик середовища, у якому функціонують конструкція, система (елемент)». Згідно з НП 306.2.141-2008 [4], під час проєктування АЕС має використовуватися обладнання, яке пройшло кваліфікацію на виконання функцій безпеки протягом строку експлуатації в умовах зміни навколишнього середовища, зокрема - під час аварій. Для діючих енергоблоків, під час розробки проєктів яких КО не проводилася, адміністрація АЕC зобов'язана організувати та виконати роботи 3 КО відповідно до розроблених ЕО і погоджених Державною інспекцією ядерного регулювання України (Держатомрегулювання) програм робіт з КО АЕС. Отже, основною метою діяльності з КО AEC $\epsilon$ гарантування спроможності виконання СВБ своїх функцій як за нормальної експлуатації, так і у разі сейсмічних впливів (CB) та можливих ЖУ навколишнього середовища під час ПА.

Регулюючі вимоги до обсягу i порядку виконання робіт 3 КО на СВ містяться В НП 306.2.208-2016 [5]. Водночас, вимоги до діяльності з КО АЕС на ЖУ ПА у нормативній базі України з ЯРБ обмежуються лише окремими положеннями, які, загалом, вказують на необхідність іiї організації та реалізації. Так, у НП 306.2.162-2010 [6] зазначається про необхідність врахування кваліфікації та старіння обладнання під час оцінки проєктних та експлуатаційних даних з метою оцінки безпеки AEC, а також під час періодичної переоцінки безпеки. Вимоги НП 306.2.099-2004 [7] i НП 306.2.214-2017 [8] стосуються врахування стану КО під час періодичної переоцінки безпеки і продовження експлуатації енергоблоків AEC у понадпроєктний строк та деталізують вимоги до процедури й обсягу аналізу даних щодо результатів КО на СВ і ЖУ ПА в межах фактора безпеки № 3 «Кваліфікація обладнання». Отже, детальні регламентуючі положення та регулюючі вимоги до обсягу і процедури КО енергоблоків AEC на ЖУ ПА в нормативних документах України з ЯРБ наразі відсутні.

У НП 306.2.141-2008 [4] зазначається, що організація і виконання робіт з КО мають здійснюватися за розробленими ЕО і погодженими Держатомрегулюванням програмними документами. Відповідно до цих вимог, процедурні та організаційно-технічні заходи з виконання КО СВБ енергоблоків АЕС Україні регламентуються Програмою ПМ-Д.0.03.476-18 [9] та стандартом СОУ НАЕК 179:2019 [10]. Для деталізації положень документів [9], [10] та врахування особливостей окремих процедур щодо КО на ЖУ ПА і КО на СВ (установлення кваліфікаційних вимог, проведення візуальних оглядів обладнання за місцем експлуатації, підвищення КО визначеними методами тощо), ЕО розроблені окремі стандарти, які регламентують обсяг і порядок виконання робіт за відповідними напрямами діяльності СОУ НАЕК 181:2019 [11] i COУ HAEK 182:2019 [12].

На основі галузевих документів (Програми [9] та стандартів [10]-[12]) EO розроблені окремі програми КО для всіх майданчиків АЕС України 3 урахуванням проєктних та експлуатаційних особливостей діючих енергоблоків. 
Практичні заходи з КО на ЖУ ПА виконуються на енергоблоках АEC України за положеннями розглянутих вище програмних і методичних документів ЕО з урахуванням вимог норм, правил і стандартів з ЯРБ (зокрема, [4] і [6]) відповідно до встановленого графіка виконання заходу № 10101 (20101, 30101) К(3)ППБ [3]. На сьогодні для 14 з 15 енергоблоків діючих AEC завершені роботи з визначення стану та підвищення КО на умови ПА. Для енергоблока № 6 Запорізької АЕС вказані роботи в стадії виконання.

Галузеві документи [9]-[12] містять основні принципи та вимоги до організації й виконання заходів з КО на СВ і ЖУ на умови ПА. Водночас, сфера застосування цих документів поширюється на такі етапи робіт, як аналіз проєктних даних та встановлення кваліфікації (визначення стану та підвищення КО). Діяльність зі збереження KO AEC положеннями зазначених документів охоплена лише узагальнено: наприклад, положеннями стандарту [10] передбачено розробку програмного документа EO, який повинен регламентувати організаційно-технічні заходи зі збереження КО АЕС. Рекомендації щодо збереження досягнутого рівня КО містяться також в окремих звітних матеріалах ЕО, розроблених за результатами вже виконаних робіт з КО енергоблоків АЕС України на умови ПА.

\section{Регулюючі вимоги щодо КО АЕС Україні для роботи в ЖУ, що можуть виникнути під час ВА}

Відповідно до положень НП 306.2.141-2008 [4], основними засобами управління запроєктними аваріями (ЗПА), зокрема ВА, на енергоблоках АEC для запобігання виникненню і розвитку аварій, обмеження їх наслідків, а також повернення реакторної установки В контрольований стан $\epsilon$ використання як СВБ, так і систем нормальної експлуатації. Стратегії керівництв з управління ВА допускають залучення всіх наявних систем енергоблоків АEC за наявності умов управління ними (електроживлення, охолоджуюче середовище тощо).

Наразі в Україні розпочато діяльність з КО на ЖУ для умов ВА. У межах цієї діяльності ЕО розроблено та погоджено з Держатомрегулюванням галузеве Концептуальне рішення [13], яке визначає підходи та обсяг діяльності з КО, а також типовий Перелік обладнання, що потребує кваліфікації на умови ВА [14]. Під час розроблення Переліку [14] враховано результати діяльності з реалізації процедур застосування нестаціонарного обладнання та заходів К(з)ППБ [3], які передбачають впровадження низки додаткових систем для збереження цілісності захисної оболонки систе- ми герметичного огородження (ГО) реакторної установки під час ВА, зокрема:

попередження раннього байпасування ГО внаслідок виходу розплаву активної зони 3 корпусу реактора - захід № 16101 (26101, 36101);

контролю концентрації водню в ГО - захід № 16201 (26201, 36201);

зниження концентрації водню в ГО для ЗПА захід № 16203 (26203, 36203);

примусового скидання тиску з ГО - захід № 16205 (26205, 36205);

аварійного та післяаварійного моніторингу захід № 14101 (24101, 34101).

3 метою виконання перерахованими вище додатковими системами призначених функцій, вимоги щодо обов'язкової кваліфікації на ЖУ ВА обладнання (елементів), які входять до цих систем, відображаються в технічному завданні на їх виробництво та постачання на AEC. Це обладнання розглядалося окремо як таке, що постачається на AEC з уже підтвердженими кваліфікаційними характеристиками, та не враховувалося під час розроблення Переліку [14].

Відповідно до Концептуального рішення [13] Перелік [14] охоплює розташоване в межах ГО обладнання проєктних систем енергоблока АEC, які можуть бути застосованими для зниження параметрів середовища (температура, тиск) у ГО під час BA:

спринклерна система;

система вентиляції.

Утім, нормативна база України регулює процес КО лише щодо ЖУ рівня ПА. Питання КО на умови ЗПА, включно 3 ВА, в наявних в Україні нормативних, програмних та методичних документах не розглядається.

\section{Аналіз міжнародного досвіду}

Через відсутність необхідних регулюючих вимог у національній нормативній базі, для формування підходів щодо організації та здійснення заходів із встановлення/ підвищення КО АЕС України на ЖУ ВА було досліджено міжнародний досвід та практику регулювання Комісії ядерного регулювання Сполучених Штатів Америки (КЯР США). КЯР США з 1993 року успішно співпрацює 3 Держатомрегулюванням та організацією його технічної підтримки (Державним підприємством «Державний науково-технічний центр з ядерної та радіаційної безпеки» (ДНТЦ ЯРБ)) в різних регулюючих сферах та надає допомогу в посилені нормативно-правової бази України з ЯРБ.

у межах цієї діяльності для фахівців Держатомрегулювання та ДНТЦ ЯРБ було 
організовано семінар, присвячений питанням КО AEC з реакторами типу BBEP на ЖУ, що можуть виникнути в разі порушень умов безпечної експлуатації (серед іншого - під час та після BA). До семінару були залучені представники Brookhaven Science Associates (BSA) (США), a також науково-технічних організацій Угорщини, діяльність яких також пов'язана з КО (зокрема, NUBIKI Ltd., VEIKI-VNL Ltd.), та AEC Paks (Угорщина). Семінар проводився на базі Науково-дослідного інституту ядерної безпеки NUBIKI Ltd. (Угорщина).

На підставі отриманих у процесі семінару відомостей виконано аналіз прийнятих у міжнародній практиці регулюючих підходів і нормативнихвимог до КО, а такожїх застосовності до регулюючої діяльності Держатомрегулювання. За результатами цього аналізу зроблено такі основні висновки [15]:

1) процеси KO AEC на ЖУ та СВ у міжнародній практиці відокремлені один від одного на рівні нормативних і програмних документів. Для них розробляються окремі програми кваліфікації і формуються окремі переліки обладнання, яке підлягає кваліфікації;

2) у міжнародній практиці під час КО на ЖУ розглядаються не лише умови ПА, але й умови ЗПА (включно з ВА). Заходи з КО АЕС на умови вихідних подій рівнів ПА, ЗПА та ВА у звітній документації АЕС наводяться як окремі рівні єдиного процесу КО на ЖУ. Статус кваліфікації обладнання («кваліфіковано»/«не кваліфіковано») визначається окремо для кожного рівня в межах єдиного комплексу робіт;

3) загальні методологічні підходи до порядку та методів реалізації окремих етапів та/або процедур КО на ЖУ ВА узгоджуються з підходами, прийнятими для КО на ЖУ ПА;

4) прийняті в Україні підходи та практика реалізації заходів з КО АЕС на умови вихідних подій проєктного рівня загалом відповідають регулюючим підходам КЯР США та міжнародному досвіду.

Підходи до регулювання діяльності з КО AЕС Україні на умови BA

у результаті аналізу національних та міжнародних підходів до встановлення та збереження КО діючих АЕС для роботи в ЖУ (включно з умовами ВА), виконаного на основі отриманого досвіду та практичних рекомендацій КЯР США, встановлено, що загальні методологічні аспекти діяльності 3 КО на ЖУ ВА не мають принципових відмінностей від відповідних підходів, установлених для КО на ЖУ ПА. Зокрема:

діяльність 3 KO АЕС на ЖУ ВА передбачає послідовне виконання таких етапів робіт, як аналіз проєктних даних, установлення КО та збереження досягнутого рівня КО; згідно з регулюючими підходами КЯР США та міжнародною практикою, процедури виконання окремих етапів робіт з КО АЕС на ЖУ ВА подібні до відповідних процедур, прийнятих для КО на ЖУ навколишнього середовища, що можуть виникнути під час та після ПА;

кваліфікація обладнання, що містить електричні компоненти (електроприводи, двигуни, кабелі, датчики тощо) проводиться переважно методом випробувань. Міжнародні підходи до обсягу і процедур кваліфікаційних випробувань обладнання АЕC цілком узгоджуються з прийнятою в Україні практикою.

Водночас, важливою частиною проведеного аналізу було визначення особливостей процесу КО на ЖУ ВА порівняно з КО на ЖУ ПА. Серед найбільш значущих висновків за результатами цього аналізу виокремимо такі [15]:

1) на відміну від ПА, режими ВА можуть супроводжуватися різкою зміною не тільки параметрів навколишнього середовища в приміщеннях, але й значним зростанням параметрів робочого тіла (теплоносія) окремих елементів АEC. Тому процес КО на умови ВА має охоплювати аналіз впливу на функціонування обладнання як ЖУ навколишнього середовища, так і ЖУ внаслідок зміни робочих режимів (внутрішнього середовища);

2) для КО на умови ВА з метою уникнення невиправданого консерватизму під час формуваннякваліфікаційнихвимогдообладнання особлива увага приділяється кількісному аналізу зміни параметрів навколишнього середовища В місці розташування обладнання залежно від вихідної події і сценарію аварії, а також функціональному аналізу для кожної одиниці обладнання (визначення необхідного характеру і часу функціонування);

3) нормативні підходи до управління ВА передбачають залучення всіх наявних систем $\mathrm{AEC}$ за можливості забезпечення їх роботи. Отже, в межах КО на ЖУ ВА потрібно розглядати обладнання всіх систем AEC, що може бути задіяне до управління ВА згідно з прийнятими стратегіями керівництв з управління ВА.

Наведені вище висновки стали підгрунтям для формування загальних методологічних підходів до регулювання процесу КО АEC України для роботи в ЖУ ВА. Ці підходи були деталізовані в проєкті регулюючого документа (керівництва) 3 кваліфікації елементів та обладнання АEC для роботи в ЖУ ВА, розробленого в межах партнерської співпраці 3 КЯР США [16]. Керівництво встановлює єдині підходи до організації та здійснення діяльності з КО на ЖУ ВА АЕС України та містить детальні вимоги до кожного з етапів процесу $\mathrm{KO}$, що може бути задіяне для управління BA, 
3 урахуванням їх взаємозв'язку із заходами, які виконуються в межах інших напрямів діяльності AEC (зокрема, технічного обслуговування i ремонту, оцінки технічного стану і продовження строку експлуатації, управління старінням, КО на умови аварій проєктного рівня тощо). Також у розробленому проєкті регулюючого керівництва наведені вимоги до процедури виконання державної експертизи (технічної оцінки) ЯРБ матеріалів EO, розроблених за результатами вказаної діяльності [16]. Зокрема, зроблено акцент на ключових науково-технічних аспектах, які мають бути в обов'язковому порядку перевірені експертом під час розгляду матеріалів із КО на ЖУ ВА, що надаються, з урахуванням досвіду виконання державних експертиз ЯРБ матеріалів з КО енергоблоків АЕС України, а саме: дотримання загального порядку (послідовності) виконання робіт з КО на ЖУ ВА;

відповідність прийнятих підходів та запропонованих рішень вимогам законів України, норм, правил і стандартів з ЯРБ, а також раніше погодженим Держатомрегулюванням документам з КО на ЖУ ВА;

нормативне та методичне забезпечення процесу КО на ЖУ ВА, зокрема - наявність стандартів, керівництв та методик, погоджених Держатомрегулюванням у встановленому порядку;

актуальність інформації щодо прийнятих вихідних даних для кожного етапу КО на ЖУ ВА, 3 урахуванням виконаних на АЕС модифікацій;

простежуваність даних (документальне підтвердження) щодо результатів виконаних на попередніх етапах КО на ЖУ ВА видів робіт;

повнота, коректність та обгрунтованість інформації щодо кожного з аспектів КО.

\section{Висновки}

За результатами вивчення міжнародних підходів і практики організації робіт з КО на ЖУ (включно з ВА), а також аналізу їх застосовності до регулюючої діяльності Держатомрегулювання, були визначені ключові методологічні аспекти організації і виконання робіт з КО АЕС на ЖУ ВА. Розроблений на їх основі проєкт регулюючого документа (керівництва) [16] може бути використаний Держатомрегулюванням під час ухвалення регулюючих рішень щодо організації і виконання ЕО заходів з КО на ЖУ ВА та оцінки їх результатів.

Також отриманий у межах співпраці з КяР США досвід дозволяє сформувати пропозиції щодо необхідності актуалізації окремих положень чинної нормативної бази України щодо КО АЕС.
Так, з урахуванням наведених вище результатів аналізу міжнародних підходів та положень національних норм, правил і стандартів з ЯРБ, можна зробити такі висновки:

1) прийняте у національних нормах, правилах і стандартах з ЯРБ визначення терміна «кваліфікація обладнання» наразі окреслює діяльність 3 КО в межах забезпечення функціональної спроможності обладнання (елементів) СВБ до рівня ПА. 3 урахуванням регламентованих К(з)ППБ [3] заходів з КО на умови ВА, зазначене визначення потребує відповідного розширення сфери КО на ЖУ, що можуть виникнути як під час ПА, так і ЗПА, включно з ВА. Також потрібно врахувати, що на відміну від ПА, стратегії управління ВА передбачають залучення не лише СВБ, але й систем нормальної експлуатації АEC;

2) нормативна базаУкраїни немістить окремого документа, що регулює питання організації діяльності 3 KO АЕС на ЖУ. Методологічний підхід щодо КО СВБ АЕС на рівень ПА в Україні регламентується на рівні програмних, методичних документів та стандартів EO, а регулюючі вимоги стосовно виконання необхідних організаційнотехнічних заходів щодо КО на ЖУ рівня ЗПА (як і відповідні стандарти ЕO) наразі відсутні. Отже, можна говорити про необхідність систематизації наявних та впровадження нових нормативних вимог щодо KO AEC на ЖУ в межах загального/ єдиного нормативного документа, за прикладом НП 306.2.208-2016 [5], що містить вимоги щодо KO на СВ. Такий нормативно-правовий акт має об'єднати в собі регулюючі вимоги щодо діяльності із встановлення та підтримання КО на ЖУ, що можуть виникнути як під час ПА, так і під час ЗПА (включно з ВА).

\section{Список використаної літератури}

1. Equipment Qualification in Operational Nuclear Power Plants: Upgrading, Preserving and Reviewing. IAEA Safety Report Series No. SRS-3. Vienna: IAEA, 1998. 120 p.

2. Periodic Safety Review of Nuclear Power Plants. IAEA Specific Safety Guide No. SSG-25. Vienna: IAEA, 2013. $106 \mathrm{p}$.

3. Комплексна (зведена) програма підвищення рівня безпеки енергоблоків атомних електростанцій. Затвердж. постановою Кабінету Міністрів України від 07.12.2011 № 1270.

4. НП306.2.141-2008. Загальні положення безпеки атомних станцій. Затвердж. наказом Держатомрегулювання 
Аналіз підходів до кваліфікації на «жорсткі» умови елементів енергоблоків АEC, працездатність яких необхідна для управління важкими аваріями на AEC

України від 19.11.2007 № 162, зареєстровані в М-ві юстиції України від 25.01.2008 за № 56/14747.

5. НП 306.2.208-2016. Вимоги до сейсмостійкого проектування та оцінки сейсмічної безпеки енергоблоків атомнихстанцій.Затвердж.наказомДержатомрегулювання від 17.10.2016 № 175, зареєстровані в М-ві юстиції України від 07.11.2016 за № 1449/29579.

6. НП 306.2.162-2010. Вимоги до оцінки безпеки атомних станцій. Затвердж. наказом Держатомрегулювання від 22.09.2010 № 124, зареєстровані в М-ві юстиції України від 21.10.2010 за № 964/18259.

7. НП 306.2.099-2004. Загальні вимоги до продовження експлуатації енергоблоків АЕС у понадпроектний строк за результатами здійснення періодичної переоцінки безпеки. Затвердж. наказом Держатомрегулювання від 26.11.2004 № 181, зареєстровані в М-ві юстиції України від 15.12.2004 за № 1587/10186.

8. НП 306.2.214-2017. Вимоги до періодичної переоцінки безпеки енергоблоків атомних станцій. Затвердж. наказом Держатомрегулювання від 30.08.2017 № 313, зареєстровані в М-ві юстиції України від 20.09.2017 за № 1158/31026.

9. ПМ-Д.0.03.476-18. Программа работ по квалификации оборудования энергоблоков АЭС ГП «НАЭК «Энергоатом».

10. СОУ НАEK 179:2019. Инженерная, научная и техническая поддержка. Квалификация оборудования энергоблоков АЭС ГП «НАЭК «Энергоатом». Общие требования. Затвердж. наказом ДП «НАЕК «Енергоатом» від 17.01.2019 № 38.

11. СОУ НАЕК 181:2019. Инженерная, научная и техническая поддержка. Квалификация оборудования, важного для безопасности, на условия окружающей среды. Общие требования. Затвердж. наказом ДП «НАЕК «Енергоатом» від 22.03.2019 № 273.

12. СОУ НАЕК 182:2019. Инженерная, научная и техническая поддержка. Квалификация оборудования, важного для безопасности, на сейсмические воздействия. Общие требования. Затвердж. наказом ДП «НАЕК «Енергоатом» від 22.03.2019 № 273.

13. КТР-М.1234.03. Концептуальное техническое решение «О квалификации оборудования, задействованного при управлении тяжелыми авариями, на «жесткие» условия окружения».

14. Перечень установленного оборудования, задействованного при управлении тяжелыми авариями, подлежащего квалификации на «жесткие» условия окружающей среды для энергоблоков АЭС. ДП «НАЕК «Енергоатом», Київ, 2018. 37 с.

15. Кваліфікація обладнання для «жорстких» умов у випадку виникнення важкої аварії (Головна Рамкова Угода № 358160, завдання № 3 від 27.03.2019): звіт про НДР. ДНТЦ ЯРБ, Київ, 2019. 38 с.

16. Кваліфікація обладнання для важких аварій (Головна Рамкова Угода №358160, завдання № 11 від 28.04.2020): звіт про науково-технічну роботу. ДНТЦ ЯРБ, Київ, 2021.89 с.

\section{References}

1. IAEA Safety Report No. SRS-3. Equipment Qualification in Operational Nuclear Power Plants: Upgrading, Preserving and Reviewing. International Atomic Energy Agency. Vienna, 1998, $120 \mathrm{p}$.

2. IAEA Specific Safety Guide No. SSG-25. Periodic Safety Review of Nuclear Power Plants. International Atomic Energy Agency. Vienna, 2013, 106 p.

3. Comprehensive (Integrated) Safety Improvement Program for NPP Units approved by Resolution No. 1270 of the Cabinet of Ministers of Ukraine on 7 December 2011.

4. NP 306.2.141-2008. General Safety Provisions for Nuclear Power Plants approved by SNRIU Order No. 162 of 19 November 2007 and registered in the Ministry of Justice of Ukraine on 25 January 2008 under No. 56/14747.

5. NP 306.2.208-2016. Requirements for Seismic Resistance Design and Evaluation of Seismic Safety of Ukrainian NPPs approved by SNRIU Order No. 175 of 17 October 2016 and registered in the Ministry of Justice of Ukraine on 7 November 2016 under No. 1449/29579.

6. NP 306.2.162-2010. Requirements for Nuclear Power Plant Safety Assessment approved by SNRIU Order No. 124 of 22 September 2010 and registered in the Ministry of Justice of Ukraine on 21 October 2010 under No. 964/18259.

7. NP 306.2.099-2004. General Requirements for NPP Lifetime Extension upon Results of Periodic Safety Review approved by SNRIU Order No. 181 of 26 November 2004 and registered in the Ministry of Justice of Ukraine on 15 December 2004 under No. 1587/10186.

8. NP 306.2.214-2017. Requirements for Periodic Safety Review of Nuclear Power Units approved by SNRIU Order No. 313 of 30 August 2017 and registered in the Ministry of Justice of Ukraine on 20 September 2017 under No. $1158 / 31026$.

9. PM-D.0.03.476-18. Program of Activities for Equipment Qualification of NNEGC "Energoatom" NPP units.

10. SOU NAEK 179:2019. Engineering, Scientific and Technical Support. Equipment Qualification of NNEGC "Energoatom" NPP Units. General Requirements approved by Energoatom Order No. 38 of 17 January 2019.

11. SOU NAEK 181:2019. Engineering, Scientific and Technical Support. Qualification of Equipment Important to Safety for Environmental Conditions. General Requirements approved by Energoatom Order No. 273 of 22 March 2019.

12. SOU NAEK 182:2019. Engineering, Scientific and Technical Support. Qualification of Equipment Important to Safety for Seismic Impacts. General Requirements approved by Energoatom Order No. 273 of 22 March 2019.

13. KTR-M.1234.03. On the Qualification of Equipment Involved in the Severe Accident Management for Harsh Environments. Conceptual Technical Solution.

14. List of Installed Equipment Involved in Severe Accident Management Subject to Qualification for Harsh Environments for NPP Units. NNEGC “Energoatom", Kyiv, $2018,37 \mathrm{p}$. 
15. Equipment Qualification for Harsh Environment under Severe Accidents (Task No. 3, BOA No. 358160 dated 28 March 2019). Technical Report, SSTC NRS, Kyiv, 2019, 38 p.

16. Equipment Qualification for Severe Accidents (Task No. 11, BOA No. 358160 dated 28 April 2020). Technical Report, SSTC NRS, Kyiv, 2021, 89 p.

\section{Analysis of Approaches to Harsh Environment Qualification of NPP Unit Components Required to Remain Efficient for the Management of Severe Accidents at NPPs}

\section{Sakhno O., Ryzhov D., Shugaylo O-r, Hamrovska L., Pavliv E.}

State enterprise «State Scientific and Technical Center for Nuclear and Radiation safety», Kyiv, Ukraine

The article analyzes the approaches adopted in Ukraine and international experience in qualifying the components of existing NPP units to operate in harsh environments that occur during NPP abnormal operation, including severe accidents. The key features of methodological approaches and procedures for equipment qualification for harsh environments under severe accidents that should be taken into account in implementing these measures are defined.

These approaches detailed in the technical guidance were developed in partnership with the U.S. NRC. The guidance establishes common approaches to the organization and implementation of the activities on equipment qualification at Ukrainian NPPs for harsh environments under severe accidents and contains detailed requirements for each qualification stage, taking into account their relationship with activities carried out within other NPP activities. At the same time, requirements for the procedure of state review (technical assessment) of NPP documents developed upon the results of the specified activity are presented in the technical guidance.

Based on the analysis of international experience and U.S. NRC regulatory practices, as well as analysis of Ukrainian regulatory requirements for the qualification of Ukrainian NPP components, proposals have been developed to update the current regulatory framework of Ukraine. These proposals indicate, in particular, the need to expand the definition of the term «equipment qualification» in the regulations to the level of not only design-basis accidents but also severe accidents. The necessity to systematize existing and implement new regulatory requirements for the qualification of NPP components for harsh environments within a separate regulatory document is also justified.

Keywords: nuclear power plant, equipment qualification, harsh conditions, severe accident, regulatory requirements.

Отримано 28.04.2021 